\title{
Targets in the breeding of spring wheat
}

\author{
TAPIO JUUTI \\ Hankkija Plant Breeding Institute \\ SF-04300 Hyrylä, Finland
}

\begin{abstract}
Growing conditions in Finland determine the earliness, protein content and reliability of the falling number as the targets for breeding spring wheat. It has not been possible to increase the earliness of spring wheat varieties from that of the local varieties cultivated before breeded varieties. On the other hand, breeding has improved the earliness to yielding capacity ratio successfully, and the ratio will be improved further in the near future. The declining trend of the average protein content in the spring wheat yields, which has caused problems in the last decade, now seems to have been corrected. The breeding material includes cultivars with a high protein content and a better ratio of protein content to yielding capacity than the varieties now cultivated. As far as the falling number is concerned, some upcoming cultivars are better adaptable to the Finnish growing conditions than the present varieties.
\end{abstract}

Index words: Spring wheat, earliness, protein content, protein quality, resistance to sprouting in the ear.

\section{Introduction}

The geographical location of Finland presents special challenges for spring wheat cultivation, as wheat is the latest spring grain grown in Finland (Mukula et al. 1977).

The speed of plant development is affected by climatic conditions, determined by means of the effective temperature sum in the place of cultivation. This sum is obtained from the mean day degrees by adding up those portions of each day's mean temperature that exceed $+5^{\circ} \mathrm{C}$. In southern Finland, where growing conditions are more favourable, the effective temperature sum is, on average, $1,300^{\circ} \mathrm{C}$. As the spring wheat varieties grown in Finland require an effective temperature sum of 1,100$1,200^{\circ} \mathrm{C}$, counted from the beginning of the growing season, in order to yellow-ripen, the temperature conditions are often critical for spring wheat (RANTANEN 1987). In some years, even the late Scandinavian varieties have not been able to ripen, the ripening of the Finnish medium-late Ruso variety occurring in late autumn (Fig. 1). If ripening is postponed to late autumn, when temperatures are low, the result is often a considerable reduction in quantity and deterioration in quality of the spring wheat yields.

In addition to temperature during the grow- 


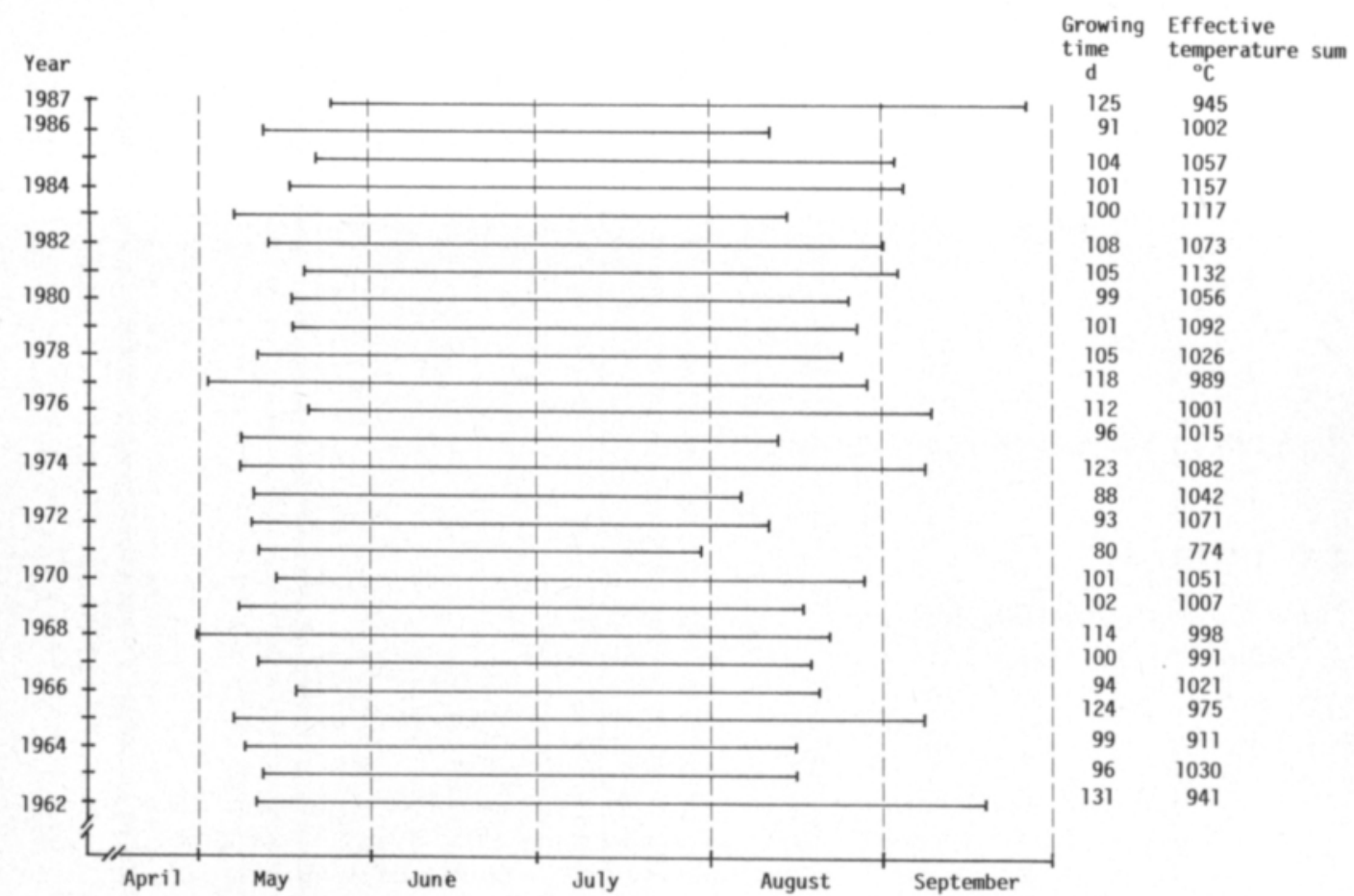

Fig. 1. The growing time and effective temperature sum requirements of Ruso, from the date of sowing to yellow ripeness, at the Hankkija Plant Breeding Institute $\left(60.42^{\circ} \mathrm{N}, 25.03^{\circ} \mathrm{E}\right)$ in $1962-1987$.

ing season, heavy rainfall constitutes a risk for spring wheat cultivation. Most of the rainfall during the growing season usually occurs between the time of ear emergency and harvesting, in August-September (Fig. 2). Moist conditions decrease the yield of spring wheat and diminishe its quality. This lower utilization value is primarily due to sprouting in the ear, but also to moulds (Mukula et al. 1977).

According to Grotenfelt (1922), spring wheat was cultivated in the southernmost parts of Finland as early as in the 14th and 15 th centuries. Its cultivation remained, however, insignificant until the 1930s, at which time the areas of cultivation started to increase rapidly. According to Pesola (1950), this growth was due to the release of Svalöf's Diamant (Diamond) variety, to the grinding protection of domestic wheat, and to summers the weather conditions of which favoured spring wheat. From 1931 to 1941 , the area under spring wheat increased from 21,900 to
117,100 hectares (KIVI 1969). This area was the greatest in 1962, covering 261,000 hectares, or $9.7 \%$ of the total arable area. In recent years, the cultivated area has varied between 90,000 and 150,000 hectares. The aim of wheat cultivation today is self-sufficiency, which has been estimated to require 200,000 hectares of cultivated land (ANON. 1987), the share of spring wheat being 65 to $80 \%$.

\section{Early breeding activity}

According to SAULI (1916), the breeding of spring wheat in Finland was based on actual native wheat varieties grown in eastern Finland in the 19th century. They were extremely early cultivars able to have ripened as far north as Lapland. Their seeds were very small, $14-20 \mathrm{~g} / 1,000$ seeds. Furthermore, they had slender straw and low yields. Breeding was also based on some spring wheat varieties cultivated at the turn of the century. Their coun- 


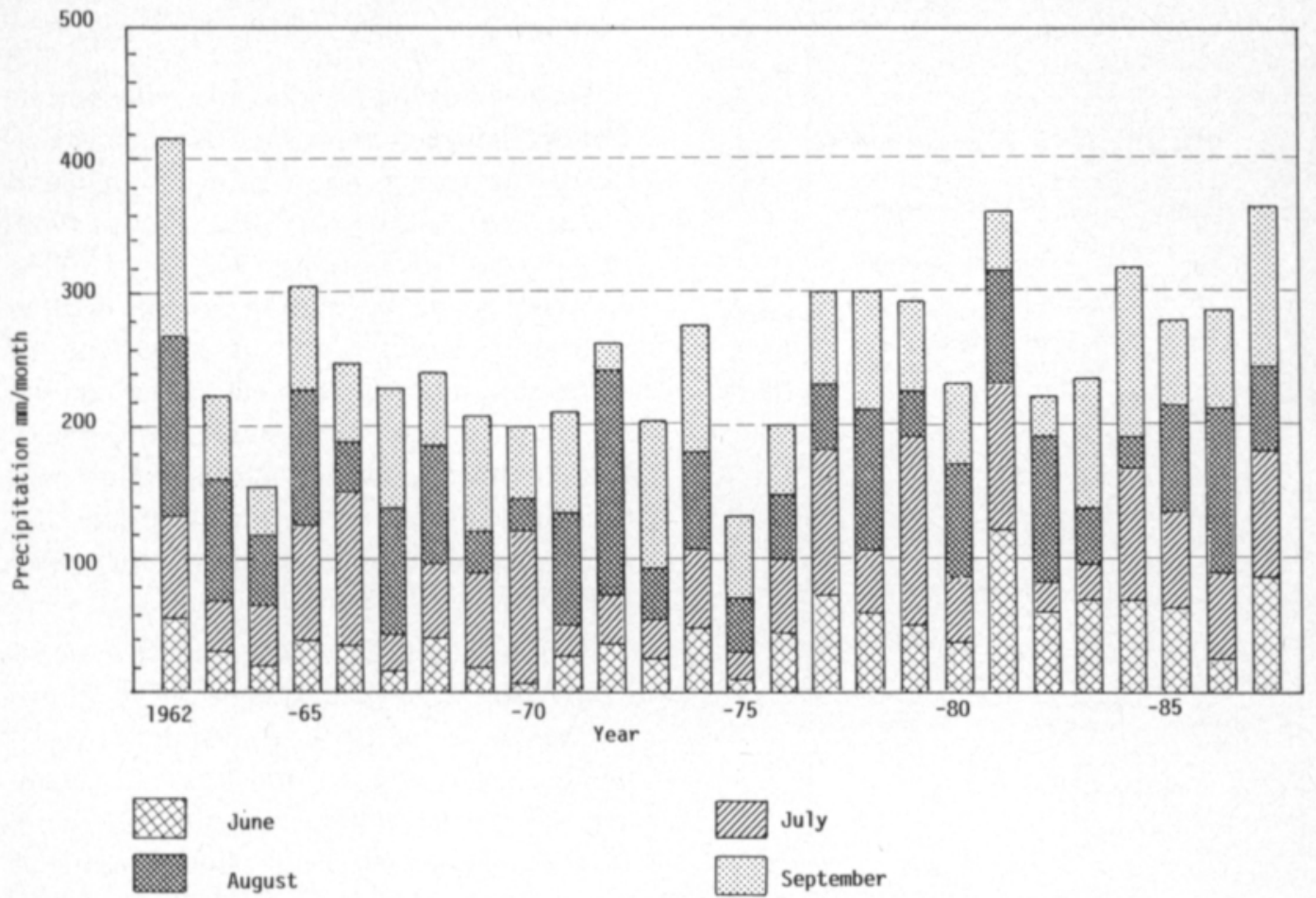

Fig. 2. Precipitation at the Hankkija Plant Breeding Institute in June, July, August, and September $1962-1987$.

tries of origin were known then, and SAULI did not regard them as genuine local wheats. The earliest variety, which also most closely resembled the local wheats, was the Siberian spring wheat, which had become grown widely in eastern Finland. On the contrary, the Sippola wheat cultivated on the Karelian Isthmus and originating in Holland and the Canadian spring wheat varieties, grown in western Finland, ripened later, but were high-yielding and stiff-strawed (Kıvı 1969). The same applied to two Swedish spring wheat varieties, Kolben and Helmi (Pärl) (SAuli 1916).

In the early stages, breeding consisted of selection from landrace populations and from mixed spring wheats which had spread to Finland at the turn of the century. As early as in the first half of the 1910s, crossings were started in order to establish a basis for selection. They were carried out with early domestic wheats and imported varieties, such as the Canadian Marquis and the Australian Aurore
(MultamäKı and Kaseva 1987). Domestic cultivars have aimed at earliness and other characteristics required in the northern fringe areas of spring wheat cultivation. Foreign wheat varieties have been sources of yielding ability, straw characteristics, quality and disease resistance, previously to yellow rust ( $\mathrm{PE}$ SOLA 1927) and nowadays mainly against powdery mildew (Erysiphe graminis, LAITINEN 1980) and the glume blotch of wheat (Septoria nodorum, Karjalainen 1985). In addition to crossbreeding, mutation breeding has been carried out to a minor extent (KIVI and Hovinen 1976).

\section{Present breeding process}

The method of selection in spring wheat breeding is the same as the partial population method applied by BJAANES (1951) in Norway (Fig. 3). According to this method, descendants of individuals selected in the $\mathrm{F}_{2}$ gener- 


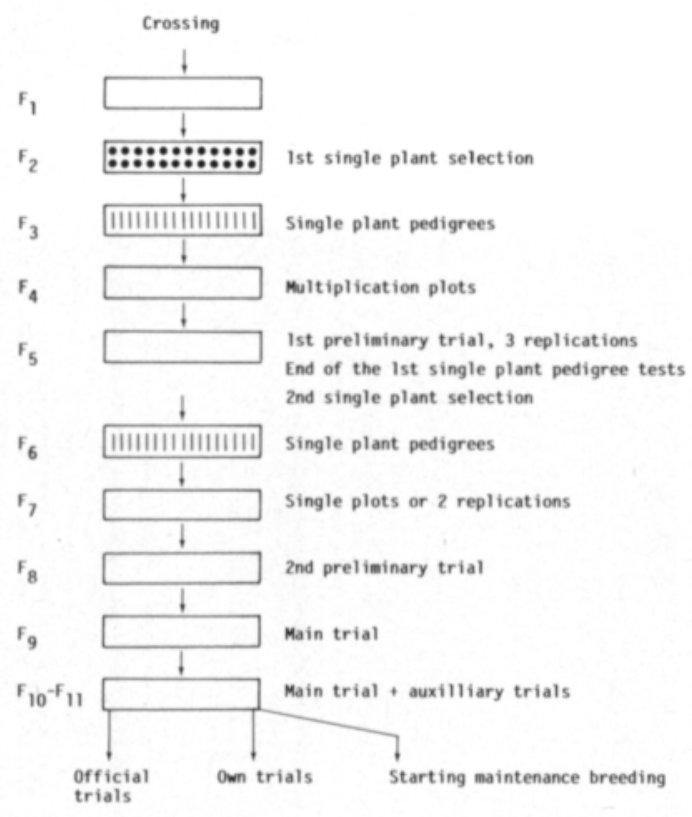

Fig. 3. Breeding scheme.

ation are selected in the $\mathrm{F}_{3}$ and $\mathrm{F}_{4}$ generations for earliness, disease resistance and straw characteristics. The selection criterias in the $F_{4}$ and $F_{5}$ generations are yield, protein content and quality, grinding characteristics and falling number.

The second individual selection is carried out in the $\mathrm{F}_{5}$ generation, after which selection is continued on the same grounds as in $F_{3}-F_{5}$. From the $F_{8}$ generation onwards selection is also carried out on the basis of gluten quantity and quality, and mixograph and moist chamber tests on falling number. Similarily, the laboratory tests on Septoria infection and the tests carried out in the field with the best lines of the main test are started in $\mathrm{F}_{8}$. In order to investigate the final baking quality, test bakings are started at the main trial stage. Using the partial population method selection on the basis of yielding reliability and yield quality characteristics can be performed in earlier generations than when the pedigree method is used, therefore without loosing the possibility of carrying out effective selection for disease resistance and earliness.

\section{Earliness}

Throughout the breeding of spring wheat, earliness has been emphasized as a characteristic of the spring wheat grown in Finland (Sauli 1920, Grotenfelt 1922, Pesola 1950, Pesola and Honkavaara 1952, Juuti 1985). As a cool period prevailed in the early decades of breeding spring wheat, the importance of earliness as a target for breeding was emphasized in the very early stages (KIVI 1969). Despite this emphasis on earliness, however, the release of new spring wheat varieties has usually led to the observation that they ripen later than the old landrace.

Almost without exception, Finnish varieties have been earlier than foreign wheats grown in Finland. In the 1920s, three Finnish varieties had been released, the Ruskea, Tammi and Pika, all Hankkija varieties. Of these, Pika was the earliest, being almost as early as the earliest local varieties. Pika was $4-5$ days earlier than Ruskea, 2-3 days earlier than the Canadian Garnet, the Swedish Rubin and Diamant and 8-10 days earlier than the Australian Aurore (SAuli 1930). Sopu, Hopea, Tammi and Pika II, which were released in the 1930 s, were all $4-7$ days earlier than the then predominant Diamant, but later than Pika (Pesola 1950). Although these varieties were earlier than Diamant and more resistant to lodging, they were not able to replace Diamant as the predominant variety. The reasons were Diamant's yielding ability and the favourable weather conditions in the 1930s.

Of the results of breeding for earliness, only the Apu variety, released in 1949 (Pesola and HonkavaAra 1952), has accounted for a noticeable share of the area under spring wheat. Apu was almost one week earlier than Diamant, and was replacing Diamant as the predominant variety (TEITTINEN and KIVI 1977). On the contrary, Hankkijan Ulla, released in 1975 (Hovinen and VARIS 1975), did not become important in the cultivation of spring wheat, although it was only one day later than Apu and had stiff straw and excellent baking qualities. 


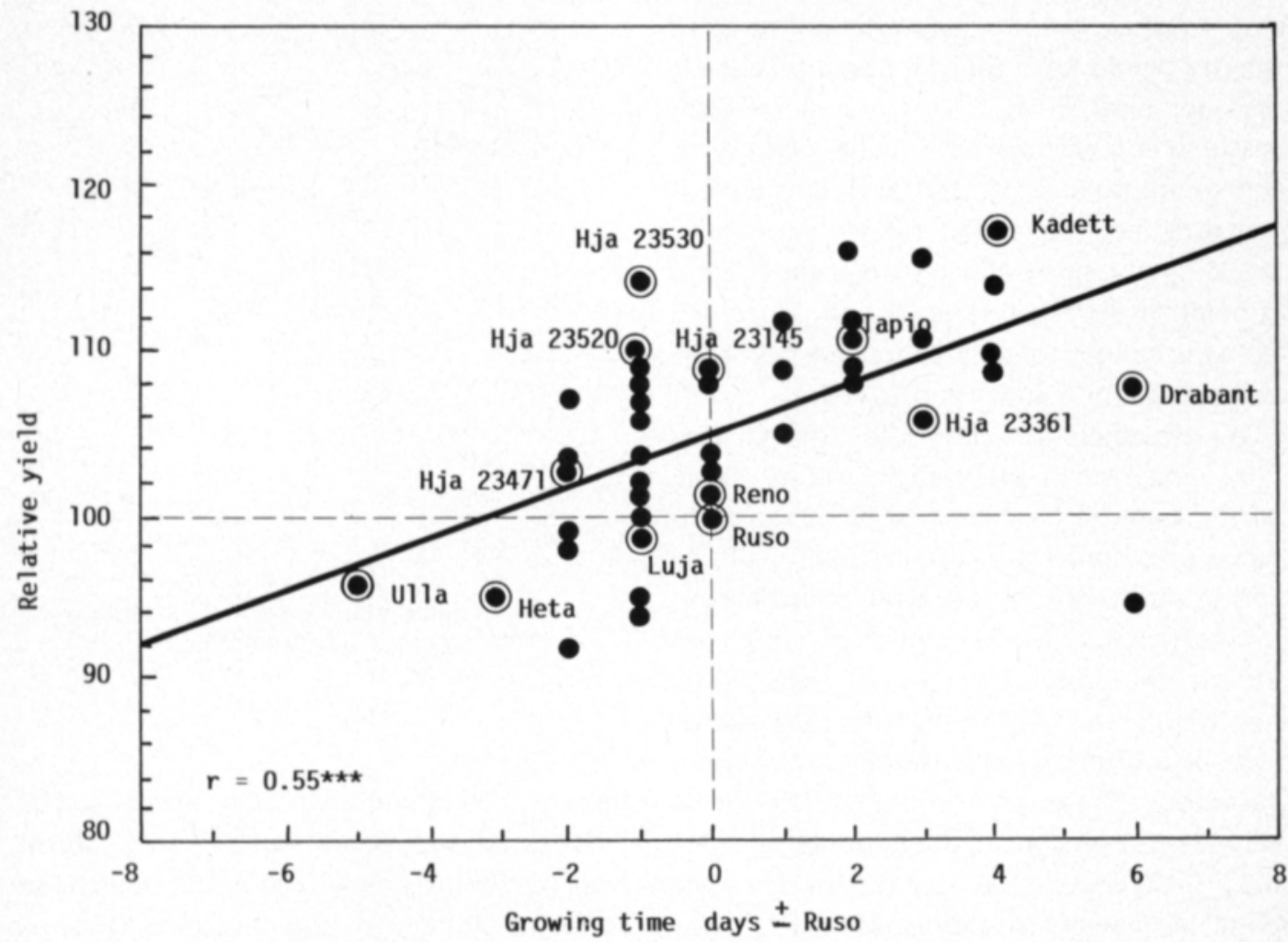

Fig. 4. Dependency of the productivity of spring wheat cultivars on the growing time, as a pair comparison with Ruso, in the Hankkija Plant Breeding Institute's tests performed in 1976-1986.

One problem encountered in the breeding of early spring wheats in Finland has been the small seed size and weak straw of the local wheats used as sources of earliness and of the cultivars bred from them. Another problem has been to shorten the growing time of spring wheat without causing the yielding ability to suffer.

In 1967, the Ruso variety was released. The ratio of its moderate earliness to yielding ability and its straw stiffness were extremely favourable as compared to other varieties of that time. Ruso became the predominant variety in the first half of the $1970 \mathrm{~s}$, maintaining it to recent years (Teitrinen and Kivi 1977, JUUTI 1985). Ruso has had the same growing time, $10 \%$ higher yielding ability and clearly stiffer straw than Diamant (KIvı 1970). Although breaking the negative interdependency of growing time and yielding ability is problematic, efforts at the Hankkija Plant
Breeding Institute have been successful as far as Ruso is concerned (Fig. 4). The breeding material contains spectra that are clearly better yielding than Ruso and somewhat earlier. On the contrary, it does not seem to be easy to breed varieties that would be one week earlier than Ruso, while having at least the same yielding ability. In the future, breeding for earliness will be hampered by the fact that the rejection of early local spring wheats in the favourable temperature conditions of the 1930 s caused the loss of the genes for extreme earliness (KIVı 1963).

\section{Protein characteristics}

In the very early stages of breeding spring wheat, special attention was not paid to quality, though the issue was a familiar one. Earliness was emphasized as the factor affecting quality in order that spring wheat would have 
time to ripen and the factors contributing to quality would have time to develop fully. It was not until in the 1930s that purposeful research into spring wheat quality and breeding to improve it started at Finnish plant breeding institutes. The research into and breeding of quality aimed then at the protein content of different varieties and concerned both the quantity and the characteristics of the protein (Pesola and Veijola 1954).

As the object of wheat cultivation in Finland today is self-sufficiency, and as spring wheat accounts for about $80 \%$ of the cultivated area under wheat, the quality of the spring wheat yield is of central importance to self-sufficiency. In the Finnish growing conditions, the protein content of spring wheat has become very important from the point of view of utilization value, because the annual variations of the protein content are great (Fig. 5). In some years the national mean of the protein content has been too low from the point of view of utilization value. Problems have also been caused over the last ten years by the declining trend in the protein content of spring wheat. Variations in protein content may be due to variety, growing place, cultivation technique and weather conditions during the growing period (Pesola and Veuola 1954, Jahn-DeERBACH 1981, JUUt 1985). According to SalovaAra (1986), one reason for the declining trend in the protein content of spring wheat is the cultivation in Finland of high-yielding and late, especially foreign, varieties. The drop of the protein content below the level critical from the point of view of baking can be prevented not only by cultivation techniques but also by the breeding of varieties with a higher protein content.

Right from the beginning, crossing method has been applied to the breeding of spring wheat to raise quality. At first, varieties in which the quality genes seemed to be good were used in crossings. Such cultivars were found in Russian, Australian and North American, especially Canadian, spring wheats. For instance, the Canadian Marquis wheat, world-renown for its quality charac-

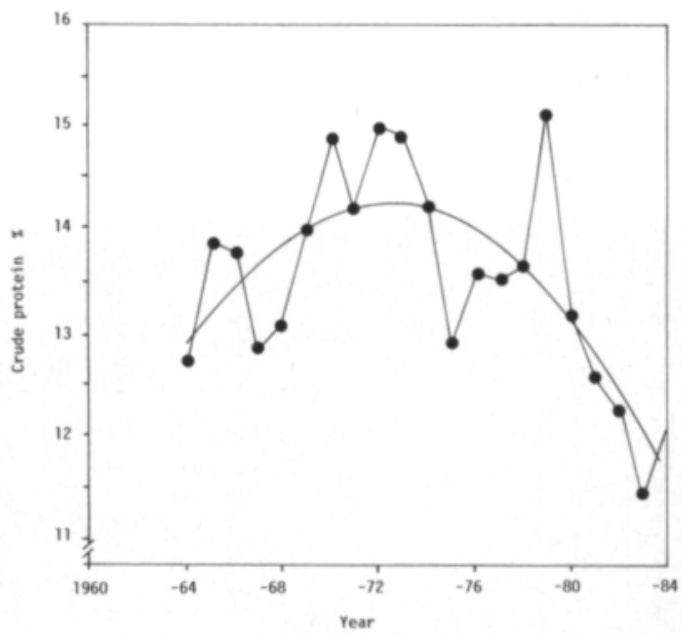

Fig. 5. Trend of the protein content of the spring wheat yield in Finland (cereal sampling).

teristics, had been used in basic crossings. The Hopea and Sopu wheats of the Agricultural Research Centre, which can be considered the result of Finnish quality breeding (PEsolA and Veisola 1954), originate in these crossings. The Hankkija Plant Breeding Institute's spring wheat varieties of Tammi and Kimmo represent the same line. Kimmo is a selection from the Russian Pissarev population, and Tammi's genotype incorporates the Canadian McIntosh (HutTunEN 1946). In addition to quality characteristics, efforts were also made to transfer rust resistance from these continental type spring wheats to domestic cultivars.

In recent decades quality breeding and, as its integral component of increasing the protein content, has been largely based on domestic varieties that are the result of such quality breeding. This work has resulted in the varieties of Ruso, Tähti, Hankkijan Ulla, Hankkijan Tapio and Luja being cultivated at present (MultamäKı and Kaseva 1987). According to official Finnish variety tests, the protein content of Ruso is 0.6 percentage units higher than that of the Swedish Kadett grown in Finland, the respective percentage units for Tähti being 1.3, for Hankkijan Tapio 0.3, for Hankkijan Ulla 2.5, and for Luja 1.2 (Mustonen et al. 1987). The fact that the 


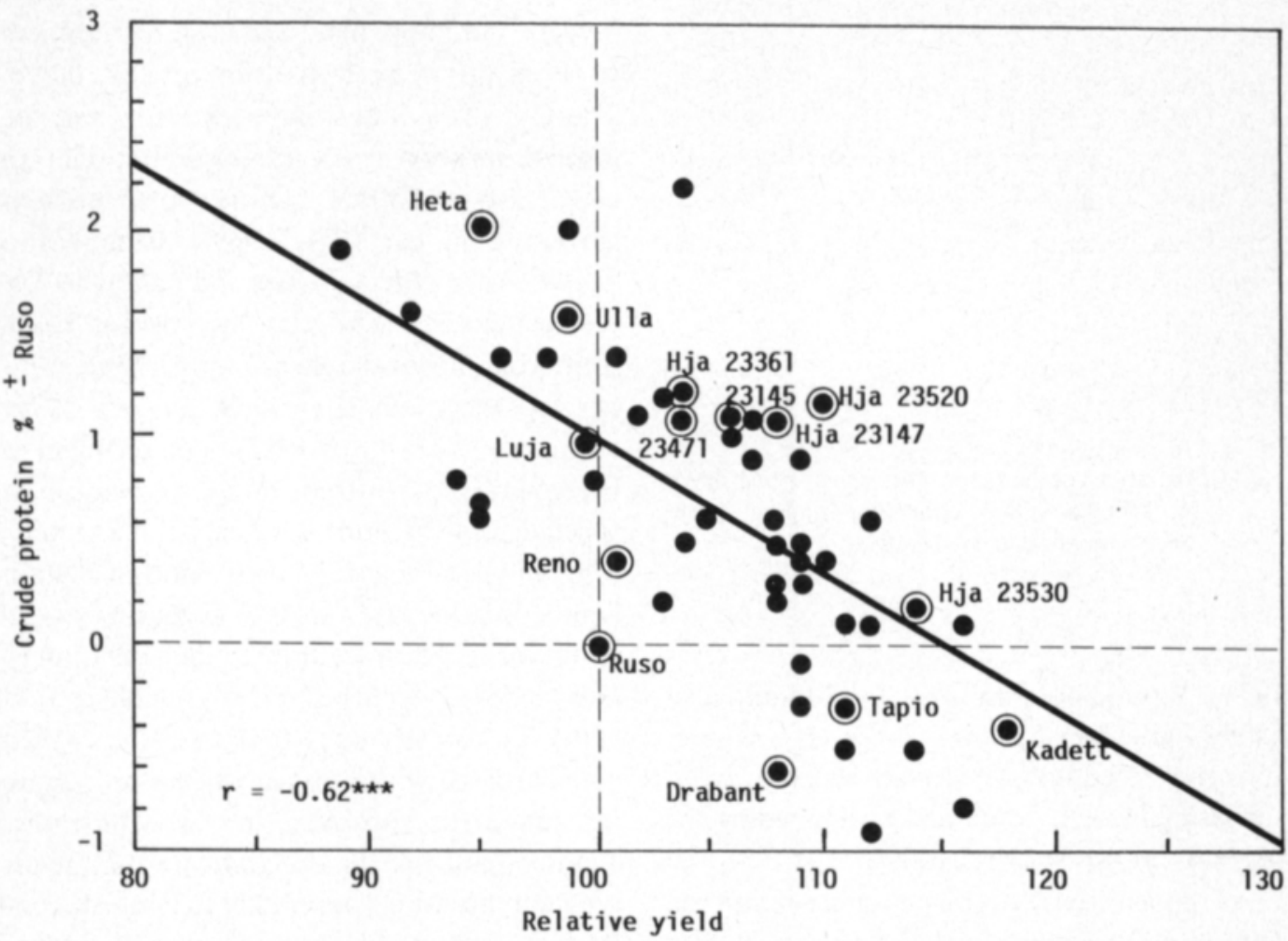

Fig. 6. Dependency of the protein content of spring wheat cultivars on productivity, as a pair comparison with Ruso, in the Hankkija Plant Breeding Institute's tests performed in 1976-1986.

Glu-1 quality value, indicating the composition of the sub-units of the large-molecule glutenin of bread wheat, is high, being 8 on average, is also largely based on this quality breeding. The value is higher than that of the British and German spring wheat varieties and the same as that of the Australian wheat (Sontag et al. 1986).

Nowadays, foreign cultivars that propagate earliness, high protein content, reliability of falling number, and yielding ability are selected to become cross parents. Combination of high protein content and good yielding ability in the same cultivar has constituted a problem in breeding for protein content. There is a negative interdependency between yielding ability and protein content. It seems, however, that efforts to break the interdependency have been successful in the newest breeding material. Genotype combinations have been found in which the ratio of yield- ing ability to protein content is better than in the varieties now cultivated in Finland (Fig. 6).

\section{Reliability at harvest}

The utilization value of spring wheat can be decisively reduced in Finland by seeds sprouting in ear before harvest. Sprouting impairs the baking and technical characteristics of spring wheat. Degraded starch is unable to bind water while baking, and therefore the inner structure of the bread breaks up and the volume remains small. Falling number tests are used to estimate damages caused by sprouting (LALLUKKA 1971). The great annual variations in falling number in Finland (Fig. 7) are most affected by weather conditions. Weather conditions preceding ripening have been found to affect the falling number, the depth and length of the dormancy of seed, and the readiness for sprouting in ear (LALLUKKA 


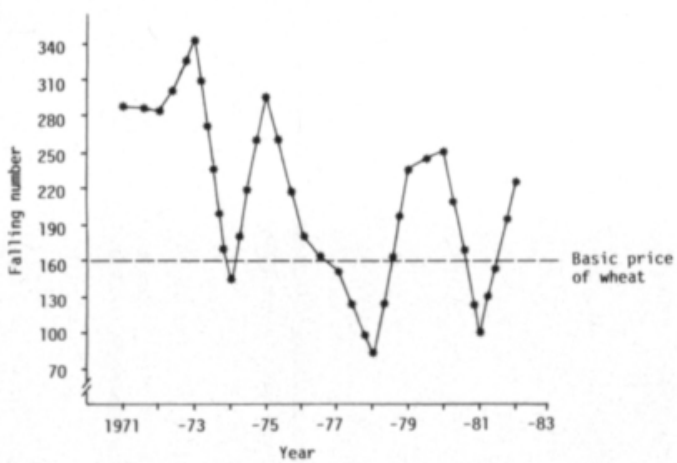

Fig. 7. Variations in the falling number of spring wheat in Finland according to the State Granary's bread cereal sampling in 1971-1982.

1971). Wheather conditions and lodging also affect the extent of sprouting in ear, wherefore the breeding of cultivars able to avoid sprouting in ear is combined with breeding for stiffness of straw (KIVI 1969).

As the sensitivity to sprouting in ear and the falling number characteristics are largely dependent on variety (KIVI 1969, LALLUKKA 1971), it is possible, by means of breeding, to reduce annual variations in the falling number of spring wheat yields. The aim has been a variety in which the time lag from a setting and drying stage of the seed which allows to combine threshing to the stage where the falling number starts to drop is as long as possible. The harvesting season for such a variety would be long. Sprouting seeds in moist sand was the first test method applied to find a genotype combination meeting this goal. Later, the moist chamber method was adopted (KIVI 1969).

The temperature in the moist chamber is $+14-+16^{\circ} \mathrm{C}$, the relative air humidity $100 \%$. Sample bunches of 30 ears are taken $4-5$ days after yellow ripeness. Four bunches of ears are taken from each cultivar. One bunch is dried immediately for use as a control. Three bunches are put into the moist chamber. The bunches are removed from the chamber after 3, 5 and 7 days. After drying, the ears are threshed and ground, and their falling numbers are determined. The figures reveal what happened to the falling numbers of the grains in a relative humidity of $100 \%$. These investigations have proved that the Finnish spring wheat varieties do not contain very good hereditary factors which prevent sprouting in ear (KIVI 1969). Tammi and Touko of the older varieties and Tähti and Tapio of the newer varieties have proved to be somewhat more reliable as far as falling number is concerned (KIVI 1969, Strand 1970, LALluKKa 1971, JUUTI 1985). The problem in breeding has been that, in a worldwide perspective, only in Northern Europe, in the maritime areas of Central Europe and in Britain is breeding for resistance to sprouting in ear of major importance in breeding for quality (KIvı 1969). It seems that it is possible to find cultivars, British ones in particular, which when crossed with Finnish wheats propagate resistance for sprouting in ear. The moist chamber test results also indicate that genotype combinations adaptable to Finnish conditions and possessing a clearly higher resistance to sprouting in ear will soon be found (Table 1).

\section{Background of the present breeding material}

In order that the breeding of spring wheat would proceed in the targets determined by cultivating conditions, variation, not only in domestic material but also extensively in materials of foreign plant breeding institutes and gene banks, has been sought the last two decades. As far as breeding for earliness is concerned, it seems that efforts to find foreign wheats that would be earlier than Finnish material have not been successful, and the earliest new cultivars are derived from crosses having a domestic cultivar as at least one party (Fig. 8). Their genotypes, in turn, have included Pika, Tammi and Garnet, or a population of Pissarev.

Good protein characteristics seem to have been propagated best by domestic cultivars, which, in turn, have included genotypes of foreign quality wheats, such as Pissarev's population, Kärn, Selkirk, Aurore and Gar- 
Earliness

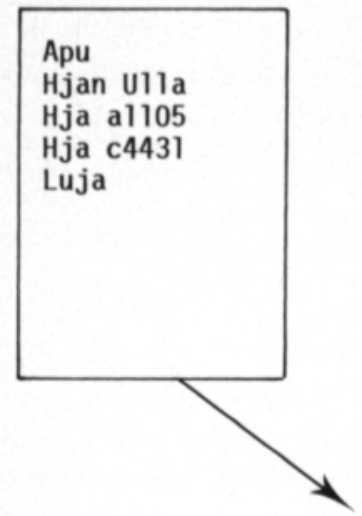

Resistance to sprouting in the ear

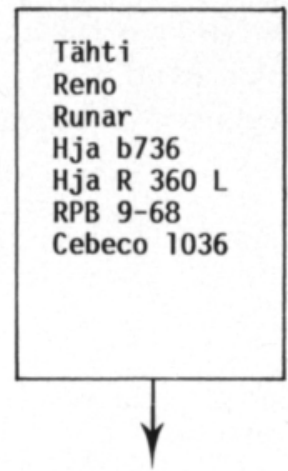

Resistance to diseases

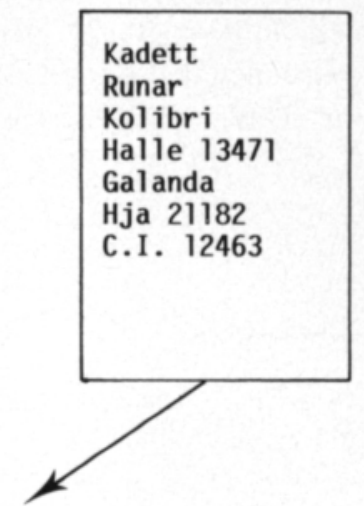

New selections

$\begin{array}{ll}\text { Heta } & \text { (Hja } 21485)(H j a \text { all05/Hja al } \\ \text { Hja 23145 } & \text { (Hja al45/Runar) } \\ \text { Hja 23361 } & \text { (RPB 9-68/Hja b736) } \\ \text { Hja 23147 } & \text { (Hja a145/Runar) } \\ \text { Hja 23471 } & \text { (Hja b736/Hja R } 360 \text { L) } \\ \text { Hja 23520 } & \text { (Sv 68372/Hja R 318 L) } \\ \text { Hja 23519 } & \text { (Sv 68372/Hja R 318) }\end{array}$

Fig. 8. Background of the present breeding material used in the Hankkija Plant Breeding Institute's targets.

net. Domestic cultivars have promoted efforts to breed a type which preserves its falling number for a long time in wet harvesting conditions. The best cultivars from this point of view have been selected from the cross populations $\mathrm{RPB}$ 9-68 (GB)/Hja b736 and $\mathrm{Hja}$ b736/Hja R 360L.

Many foreign cultivars have been applied

Table 1. The moist chamber figures of falling numbers for the breeding material of spring wheat, as a pair comparison with Ruso, in the Hankkija Plant Breeding Institute's tests performed in 1982-1986.

\begin{tabular}{|c|c|c|c|c|c|c|}
\hline \multirow[t]{2}{*}{ Cultivar } & \multirow[t]{2}{*}{$\mathrm{n}$} & \multirow{2}{*}{$\begin{array}{c}\text { Growing } \\
\text { time } \\
\text { d }\end{array}$} & \multicolumn{4}{|c|}{$\begin{array}{l}\text { Falling number, after keeping } \\
\text { in moist chamber }\end{array}$} \\
\hline & & & 0 & 3 & 5 & 7 days \\
\hline Ruso & 9 & 102 & 199 & 123 & 64 & 62 \\
\hline Tähti & 9 & +6 & +36 & +26 & +5 & +1 \\
\hline Kadett & 8 & +3 & -4 & +11 & +18 & -2 \\
\hline Hjan Tapio & 8 & +2 & +1 & +40 & +37 & +4 \\
\hline Luja & 5 & -1 & +48 & +20 & +12 & +0 \\
\hline Hja 23456 & 3 & +2 & +146 & +186 & +118 & +76 \\
\hline Hja 23361 & 4 & +3 & +136 & +65 & +68 & +35 \\
\hline Hјa 23447 & 2 & +2 & +155 & +110 & +134 & +61 \\
\hline Hјa 23329 & 4 & -1 & +100 & +184 & +171 & +43 \\
\hline Hja 23471 & 3 & -3 & +167 & +245 & +123 & +25 \\
\hline
\end{tabular}


in breeding for resistance to powdery mildew and Septoria. The genotypes of the cultivars which have got the farthest in the selections have included Kadett, Runar, Reno, Kolibri, or Halle 13471. The cultivars Galanda,
C.I.12463, Kadett, and $\mathrm{Hja} 21182$ have been used because infections and the droplet tests have proved them to be the varieties which most effectively resist Septoria in Finnish conditions.

\section{References}

ANON. 1987. Erikoiskasvitoimikunnan mietintő. Komiteamietintö 1987, 33: 1-218. Helsinki.

BJAANES, M. 1951. Undersøkelser i vårkveiteforedling Meld. fra Stat. forsøksgard Møystad. nr. 42: 84-139.

Grotenfelt, G. 1922. Vehnänviljelys. Suomalainen peltokasvien viljelys II 1922: 49-68.

Hovinen, S. \& VARIS, E. 1975. Hankkijan Ulla -kevătvehnä. Summary: Hankkija's Ulla spring wheat. Hankk. Siemenjulkaisu 1975: 142-143.

HuttunEN, E. 1946. Tammiston uusimmat kauppaanlasketut jalosteet. Summary: The newest marketed varieties of Tammisto. Hankk. Siemenjulkaisu 1946: $128-131$.

Jahn-Deerbach, W. 1981. Untersuchungen über den Einfluss von Klimafaktoren auf Ertrag und Qualität von Weizen (Klimakammerversuche). Das Getreide, Mehl und Brot 1981: 281-286.

Juutı, T. 1985. Kevătvehnä. Hankk. Siemenjulkaisu 1985: 46-53.

Karjalainen, R. 1985. Host-pathogen interaction between spring wheat and Septoria nodorum with reference to resistance breeding. J. Agric. Sci. Finl. 57: $1-66$.

KIvı, E. 1963. Domestic plant breeding for the improvement of spring cereal varieties in Finland. Acta Agr. Fenn. 100, 3: 1-37.

— 1964. Några finska văxtförädlingssynpunkter. Nord. Jordbr.forskn. Suppl. 8: 197-199.

- 1969. Sadon kảyttőarvo kevätvehnänjalostuksen tavoitteena. Summary: Quality properties in Finnish spring wheat breeding. Ann. Agric. Fenn. 8: 193-204.

- 1970. Kevătvehnă. Summary: Spring wheat. Hankk. Siemenjulkaisu 1970: 35-41.

- 1984. Prospects for northern plant breeding. The Hankkija Plant Breeding Institute, Communication 19: $1-21$.

— \& Hovinen, S. 1976. A mutation breeding programme for sprouting resistance in the bread wheat. J. Agric. Sci. Finl. 48: 347-355.

LAITINEN, A. 1980. Taudinkeståvyysjalostus. Summary: Resistance breeding. Hankk. Siemenjulkaisu 1980: $111-115$.

LALluKKA, U. 1971. Eräiden ulkoisten tekijöiden ja kasvin morfologisten ja fysiologisten ominaisuuksien vaikutus kevătvehnän tăhkäidăntään. Summary: Effects of certain external factors and of the morphological and physiological characteristics of the plant upon the sprouting in the ear of spring wheat. J. Agric. Sci. Finl. 121: $1-100$.

Mukula, J. Rantanen, O. \& LallukKa, U. 1977. Kevătvehnän viljelyvarmuus Suomessa 1950-1976. MTTK, Kasvinviljelylaitoksen tiedote nro 8: 1-72.

Multamä́ı, K. \& Kaseva, A. 1987. Domestic varieties. MTTK, Tiedote 11/87, Kasvinjalostusosasto.

Mustonen, L., Pulli, S., Rantanen, O. \& Mattila, L. 1987. Virallisten lajikekokeiden tuloksia 1979-1986. MTTK, Tiedote 7.

PEsola, V.A. 1927. Kevätvehnän keltaruosteen kestävyydestä. Summary: On the resistance of spring wheat to yellow rust Puccinia glumarum. Valt. Maatal.koetoim. Julk. 8: 1-176.

- 1950. Kevătvehnän jalostustyöstä Jokioisissa. Maatal. ja Koetoim. 4: 211-221.

- \& HonkavaAra, T. 1952. Apu-kevätvehnä. Valt. Maatal.koetoim. Tied. 228: 1-12.

— \& VEIJOLA, T. 1954. Vehnän kvaliteettijalostuksesta ja sen tuloksista Suomessa. Summary: On breeding for quality of wheat in Finland. J. Agric. Sci. Finl. 26: 178-194.

RANTANEN, O. 1987. Värme och nederbörd samt dessas betydelse för vår sădesodling. LOA 9/87: 346-348.

SalovaAra, H. 1986. Experiencies of testing wheat cultivars in industrial baking. Acta Agric. Scand. 36: 225-239.

SAULı, J.O. 1916. Kevătvehnälaaduista ja niiden viljelyksestă meillä. Hankk. Siemenjulkaisu 1916: 17-21.

- 1920. Havaintoja ja koenumeroita kevătvehnän jalostuksesta Tammistossa. Ibid. 1920: 70-75.

— 1930. Kevătvehnả. Ibid. 1930: 47-49.

Sontag, T., Salovaara, H. \& Payne, P.J. 1986. The high-molecular glutenin compositions of wheat varieties bred in Finland. J. Agric. Sci. Finl. 58: 151-156.

Strand, E. 1970. Spiretreghet hos sorter og foredlingsmateriale av høsthvete, vårhvete, bygg og havre. Meld. fra Norges Lantbr. Høgsk. 49, Nr 2: 1-22.

Teittınen, P. \& Kıvı, E. 1977. Tärkeimmät peltokasvilajikkeemme. Koetoim. ja Käyt. 29. 3. 1977.

Ms received 1988 


\section{SELOSTUS}

\section{Kevätvehnän jalostustavoitteiden painopisteet}

\section{Tapio Juuti}

Hankkijan kasvinjalostuslaitos

04300 Hyrylä

Kasvuolomme määrãăvăt kevătvehnänjalostuksen painopistealueiksi aikaisuuden, valkuaissisăllön ja sakolukuvarmuuden. Aikaisuutta ei ole kyetty lisaaămăaan siitä, mită se oli ennen jalostettujen lajikkeiden viljelyyn tuloa viljellyillă maatiaiskevătvehnillă. Sen sijaan kevătvehnăn aikaisuus-satoisuus suhdetta on pystytty jalostuksen kuluessa parantamaan ja se on lăhitulevaisuudessa vielă paranemassa. Viime vuosina huolta aiheuttanut kevătveh-

näsadon valkuaispitoisuuden laskeva suunta näyttäă korjaantuvan, sillă jalostusaineistoissa on jalosteita, joitten valkuaispitoisuus on korkea ja valkuaispitoisuus-satoisuus suhde parempi kuin nykyisin viljeltävillä jalosteilla. Myös sakolukuominaisuuksiltaan Suomen oloihin nykyisiă lajikkeita paremmin sopeutuvia jalosteita näyttää olevan näköpiirissă. 